\title{
Interactive Effects Of Rhizobium And Virus Inocula On Symptomatology And Nodulation In Cowpea.
}

\author{
Oyatokun, O. S. ${ }^{1}$, Okogun, J. A. ${ }^{1,2}$, Shoyinka, S.A. ${ }^{2,3}$ \\ 1. (Department of Agronomy, University of Ibadan, Ibadan, Nigeria) \\ 2. (International Institute for Tropical Agriculture, P.M.B.5320, Ibadan, Nigeria) \\ 3. (Institute of Agricultural Research \& Training, Moore plantation, Ibadan)
}

\begin{abstract}
A study was carried out to evaluate the interactive effects of rhizobium and virus inocula on three cowpea cultivars: Ife brown, Owode and IT90K-277-2 on sterilized soils in the greenhouse. The cultivars were inoculated with two strains of rhizobium, R25B and IRj2180A, and two strains of virus, cowpea aphid-borne mosaic virus (CABMV) and cowpea yellow mosaic virus (CYMV), 7 days after planting (DAP) regarded as early inoculation and 21 DAP as late inoculation.

The trial was a factorial experiment fitted into split-split plot design. Viral inoculation significantly reduced the numbers of nodules and nodule weight, biomass production and grain yields of all the three cowpea cultivars. Maximum reductions were obtained with the viral infections where rhizobium inoculants were absent. Time of inoculation also had a significant impact on the effect of the inoculums strains. Early inoculation provided a significant result than late.

The interaction of rhizobium and virus inoculums strains indicated that the severity of infection by the viral strain was not in any way depressed by the presence of rhizobium inoculums strains. There were no variations in varietal reactions.

Cultivar IT90K-277-2 possessed a superior genotype while Ife brown cultivar exhibited the least performance in terms of most parameters measured.

Keywords: biomass, cowpea, inoculation, nodulation, rhizobium, virus.
\end{abstract}

\section{Introduction}

Cowpea [Vigna unguiculata L. Walp] also called southern pea or black-eye pea is an important food and fodder crop in the sub-humid tropics of Africa (Singh and Rachie, 1985; Ng and Monti, 1990).

The recognition of cowpea lies in its intrinsic characteristics to double as food crop and as soil fertility restorer. As a food, the grain is a protein staple (Marconi et al., 1990) and provides an important source of dietary protein, especially for the population of West Africa, where two-third of the world's cowpea grain is produced. Its association with some bacteria, notably rhizobia, further enhances the latter character. These organisms symbiose with most leguminous crops.

Cowpea yield is influenced by a number of factors, which include genetic make-up of the seed, seed quality, management practices or crop husbandry, effects of pests and diseases, availability of and competition for growth factors such as water, nutrients and light. The dry grain yields of traditional varieties have been low. The low yield in Africa, Asia and Latin America is generally attributed to poor husbandry, insect pests and diseases, drought and poor plant type (IITA, 1989; Marconi et al., 1990).

Symbiosis is a term commonly adopted to cover mutualism, where each organism was presumed to derive benefits from an association between two organisms. From an ecological standpoint, the organism gains an overall net benefit from the complex reactions of its living habitat and in no means contribute harm to the environment or put it at a selective disadvantage (Lewin, 1982).

Legume-rhizobia symbiosis results in the fixation of the atmospheric nitrogen in the soil. For those species of plant, which are capable of utilizing atmospheric nitrogen for growth, this provides a much cheaper source of $\mathrm{N}$ than nitrogenous fertilizer.

While the plant furnishes the bacteria with photosynthate to the competitive advantage of the corresponding microbial symbiont in the rhizosphere, the bacteria possess the enzymes capable of reducing atmospheric $\mathrm{N}$ into compounds assimilable by the host plant (Stacey et al., 1992).

Nitrogen is a key element required for plant growth and the symptoms of its deficiency range from poor yield to crop failure. Under conditions of $\mathrm{N}$ limitation, rhizobium bacteria infect leguminous plants, which then form root nodules. In the process, the bacteria present in the nodules (as bacteroids, differentiated forms of bacteria) fix atmospheric $\mathrm{N}$ and convert this into ammonia, which is used as nitrogen source by the plant (Lugtenberg, 1992). In return, the plant provides the bacteria with a carbon source.

Apart from this mutually beneficial (healthy) relationship between crop plant and microorganisms, plant-microbe interaction could also result in an unhealthy relationship, which may trigger crop failure and food 
shortages. Such is the case between viruses and crop plants. Viruses are biological enigma. They are totally dependent on their host for existence and exhibit extremely specific intracellular parasitism. Viruses have the ability to infect, and can be transmitted from one host to the other (Cooper and MacCallum, 1984).

The interaction between plants and microorganisms has been studied for both isolated and complex systems. The organisms of these systems react in the interaction within the microhabitat rather than in isolated cultures, however, there is a possibility of interaction between different plant microorganisms.

A more detailed knowledge about the relationship or the interactive effects of plant microbes (beneficial or harmful) has the goal of improving productivity and will allow development of new biological methods for the control of parasites, of plant protection or for increasing yields.

This work has as its thrust the interactive effects of rhizobium and virus inocula on cowpea with respect to disease resistivity and $\mathrm{N}$ fixing ability of the crop; with the following objectives:

- to evaluate the effect of virus inoculation on the biomass yield and nodulation

- to assess the potency of rhizobium in resisting viral infection in various cowpea cultivars, and

- to evaluate the effect of time of inoculation of rhizobium on cowpea susceptibility to viral infection.

\subsection{Experimental location, soil sampling and analysis}

\section{Materials and methods}

The experiment was carried out in the greenhouse of the IITA, Ibadan, Nigeria.

Composite soil samples were taken from IITA premises and a sub-sample was used for pre-cropping soil analysis.

\subsection{Preparation of inocula / inoculation buffer for virus}

Pure cultures of rhizobium strains: R25B and IRj2180A were aseptically grown in separate conical flask containing yeast mannitol broth prepared according to Vincent (1970). Virus inoculum strains: CABMV and CYMV were prepared by grinding the leaves of infected propagative host (Ife brown) separately in $0.05 \mathrm{M}$ K2HPO4 buffer solution using pestles and mortals which had been sterilized in an oven.

\subsection{Experimental procedures, design and analysis}

Soils obtained from IITA were sterilized by the sterilizing unit of the institute. This was to eliminate the soil inhabiting microorganisms. The sterilized soils were then filled into plastic pots and arranged in the greenhouse. All wares such as petri dishes, pipettes, test tubes, conical flask, pestles and mortars, etc and seeds were sterilized to avoid contamination. The experiment was a factorial experiment arranged in a split-split plot design with two replications, using 3 cowpea cultivars, 9 inoculum strains at 2 different times of inoculation, thereby giving a total of 54 pots per replicate. ANOVA was carried out on all the data obtained according to SAS systems on the basis of the experimental design. Treatment means were compared using Duncan Multiple Range Test (DMRT) at 5\% level of significance.

\subsection{Planting}

The seeds of the 3 cultivars: Ife brown, Owode and IT()K-277-2 that had been previously sterilized were planted at the rate of 4 seeds per pot and later thinned to 2 seeds per pot.

\subsection{Inoculation}

Sterile pipettes were used to transfer $1 \mathrm{ml}$ of rhizobium culture to the root of seedlings at 7 days after planting (DAP) and 21DAP regarded as early and late inoculation respectively. Seedlings were mechanically inoculated with virus inocula early and late as well. Virus inoculum strains were rubbed on the leaves previously dusted with carborundum. Leaves are then rinse with tap water immediately after inoculation. All control plants were not inoculated.

\subsection{Spraying}

Seedlings were first sprayed with azodrine insecticide 3 weeks after planting (WAP) and in subsequent 2 weeks interval at an application rate of $1 \mathrm{ml} /$ liter to control insects attack.

\subsection{Measurement of parameters}

Growth parameter measured was the mean plant height at 3WAP and 5WAP. Also, symptoms (response to infection) were measured using a scoring system at $3 \mathrm{WAP}$ and 5WAP. The scoring scale used include low infection (1), moderate (2), high (3), severe (4) and very severe/death (5). Other parameters measured include nodulation, biomass production and grain yields. 


\subsection{Nodule harvesting}

Nodules were harvested at $6 \mathrm{WAP}$ by removing the soil in running water through a 30 -mesh screen, surfaced-dried with paper towels, sealed in a small plastic bag and stored at $4^{\circ} \mathrm{C}$.

\subsection{Plant tissue analysis}

Finely ground dried plant (shoot) samples were used to determine the total $\mathrm{N}$ using the macro Kjeldahl method (Bremmer and Mulvaney, 1982). The percent $\mathrm{N}$ was then multiply by 10 to express the total $\mathrm{N}$ content in $\mathrm{g} / \mathrm{kg}$.

\section{Results and discussion}

The soil was of medium acidity $(\mathrm{pH}=6.0)$. The exchangeable bases were above the critical values. The available $\mathrm{P}$ was high $(24.2 \mathrm{mg} / \mathrm{kg})$ as well as the total $\mathrm{N}$ content $(5.6 \mathrm{~g} / \mathrm{kg})$ and organic $\mathrm{C}(55.9 \mathrm{~g} / \mathrm{kg})$. The particle size analysis showed that the textural class of the soil is loamy sand.

There was a significant difference in plant height of cultivar IT90K-277-2 and the other two cultivars (Ife brown and Owode), although both responded similarly in terms of height (Table 1). Cultivar reactions to biomass production indicated that IT90K-277-2 produced higher biomass than Ife brown and Owode (Table 1) and this might be due to the genetic make-up of the cultivars. Cultivar reaction to viral infections increases with age (i.e. ranges from moderate at $3 \mathrm{WAP}$ to high at $5 \mathrm{WAP}$ ), although there was no variation among the three cultivars studied. There were also variations in cultivar reactions to nodulation with Owode producing the highest number of nodules while Ife brown produced the lowest (Table 1). The cultivar effects on grain yield and N-uptake also showed a significant variation. While IT90K-277-2 produced the highest grain yield $(0.74 \mathrm{~g} / \mathrm{plant})$, Owode produced $0.58 \mathrm{~g} / \mathrm{plant}$ and Ife brown $0.40 \mathrm{~g} / \mathrm{plant}$. However, tissue analysis revealed that IT90K-277-2 also had a significantly higher N-up take than the other two cultivars, Ife brown and Owode respectively (Table 1). This indicated that IT90K-277-2 had superior genetic make-up than the other two cultivars (Ife brown and Owode).

The influence of the inoculums strains on plant height, response to infection, biomass production, nodulation, grain yield and $\mathrm{N}$-uptake are presented in Table 2. Cowpea plants that received rhizobium inoculum strains were tallest while those that received virus inoculum strains produced the shortest plants. The reason for the reduced growth of the viral infected plants was that the viruses had some impaired effects on the growth of cowpea plants. This agreed with previous work by Tu and Ford (1984). However, the interaction of the inoculums strains showed that R25B + CYMV and IRj2180A + CYMV produced significantly higher growth response than R25B + CABMV and IRj2180A + CABMV. This indicated that the extent of the infection between rhizobium strains with CYMV was less than with CABMV. It also suggested that CABMV was more exerting than CYMV in depressing the growth of cowpea.

With regards to response to infection, cowpea cultivars inoculated with inoculum strains R25B, IRj2180A and the control showed a uniformly moderate signs of infection. The infection was probably seedborne, however, those inoculated with virus inoculums strains, CABMV and CYMV, showed a marked difference. The viral infection was observed to be more severe in the absence of rhizobium inoculums than when applied (Table 2). This variation in the degree of severity of viral infection may be due to low uptake of $\mathrm{N}$ in those plants not inoculated with rhizobium. A similar result had been reported by O'Hair and Miller (1982) who reported that cowpea strains of TMV resulted in most severe symptoms and was associated with a reduction in nitrogenase activity. However the interaction of rhizobium and virus inoculums strains indicated that the severity of the viral strains was not in any way depressed by the presence of rhizobium inoculums strains.

The biomass production of cowpea plants varied in response to different inoculums strains. Rhizobium inoculums strains enhanced the biomass production of cowpea cultivars (Table 2). Similar result had been reported (Sanginga et al., 2000) that R25B and IRj2180A both nodulate well and produce higher shoot dry matter on soyabean cultivated on sterilized or unsterilized soils. Cowpea cultivars that were inoculated with viral strains showed reduction in their biomass production. The interaction of rhizobium and virus inoculum strains on cowpea plants also showed reduction in the plants biomass (Table 2). The morphological disturbances as well as physiological abnormalities due to virus infection in roots of plants have also been reported in the literature (Panopoulos et al., 1972, Shoyinka, et al., 1997).

Nodulation was highly depressed by CABMV and CYMV. The depression was probably due to virus replication causing physiological changes of reduced photosynthesis or increased respiration $(\mathrm{Tu}$ and Ford, 1984), imbalanced auxins and enzyme levels which directly or indirectly affected the rhizobium-cowpea symbiotic relationship. Ineffective symbioses are characterized by small nodules that fail to grow to normal size because the degeneration that starts in the bacterial region quickly spreads to the nodule meristem and stops its growth (Nutman, 1958). O'Hair and Miller (1982) reported that cowpea strains of TMV were associated with a reduction in total nodules weight and nodules numbers. Rhizobium strains, R25B and IRj2180A, enhanced 
nodulation in cowpea (Table 2). However, the interaction of rhizobium and virus strains showed variations in nodulation while $\mathrm{R} 25 \mathrm{~B}+\mathrm{CYMV}$ and IRj2180A+CYMV gave a slight reduction in nodulation. This indicated that the extent of interaction between the rhizobium strains with CYMV was less than with CABMV. It further suggested that CABMV was more pathogenic than CYMV in depressing nodulation. It was also observed that that rhizobium strains $\mathrm{R} 25 \mathrm{~B}$ in the interaction enhanced nodulation in the rhizobial-viral interaction than IRj2180A. This might mean than R25B was more resistant to viral attack than IRj2180A. There are significant differences among rhizobial isolates with regards to infectivity and effectivity (Wijesundara et al., 2000). There appeared to be a positive correlation between the number of nodules and nodules weight.

Inoculation also affected grain yield and $\mathrm{N}$-uptake of cowpea plants. Rhizobium inoculum strains (R25B and IRj2180A) produced the highest grain yields $(0.98 \mathrm{~g} / \mathrm{plant})$ followed by the control $(0.91 \mathrm{~g} / \mathrm{plant})$, R25B+CYMV (0.79g/plant), R25B+CABMV (0.53 g/plant), IRj2180A+CABMV (0.45 g/plant), IRj2180A+CYMV (0.36 g/plant), CYMV $(0.15 \mathrm{~g} /$ plant $)$ and the least CABMV which had a zero yield. N-uptake obtained from the plant tissue analysis followed a similar pattern with grain yield. Inoculum strain R25B had the highest N-uptake (5.38g N/plant), followed by IRj2180A (5.32), Control (4.61), R25B+CYMV (3.78), IRj2180A+CYMV (3.64), R25B+CABMV (3.01), IRj2180A+CABMV (2.74), CYMV (1.42), and the least, CABMV (1.17). This indicated that rhizobial inoculation enhanced $\mathrm{N}$-uptake in cowpea while viral inoculation suppressed it. It further reinforced the assertion that CYMV was less pathogenic than CABMV in the rhizobial viral interaction.

Time of inoculation was observed to affect various parameters of cowpea cultivars measured. The growth response of the cultivars was slower when the inoculation was carried out early than late (Table 3 ). However, the response of the cultivars to infection indicated that greater havoc was wrecked and this became more devastating with the age of the plants, when inoculation was done early than when it was done late. This indicated that the virus inoculum strains interfered with physiological and metabolical processes of the plant at early stage of growth causing a greater damage than when applied later. Similar results had been reported by Chant (1960) and Shoyinka (1974) who reported that the earlier the infection the greater the yield reduction, although even with infection as late as six weeks after planting, significant yield reductions occur.

The grain yield of cowpea cultivars observed was fairly more uniform irrespective of the time of inoculation (Table 3). This was in agreement with previous work by Allen and Lenne (1998) who reported that yield losses vary widely, depending on the susceptibility of the cultivars, the virus strain, time of infection and environmental condition but contrary to the works of Agrios et al. (1985) and Kareem and Taiwo (2007) who reported that the younger the plants at the time of viral infection, the greater the severity of disease symptoms. However, the plants $\mathrm{N}$-uptake were higher when inoculation was done late than when done early (Table 3). This indicated that there was early interference on the plant metabolic and physiological processes, hence low $\mathrm{N}$ uptake (O'Hair and Miller, 1982; Tu and Ford, 1984).

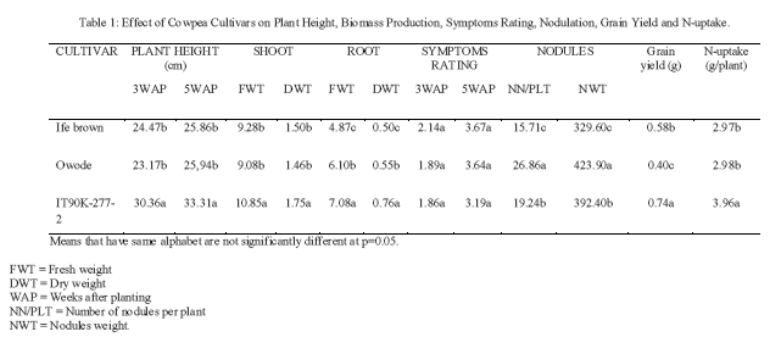




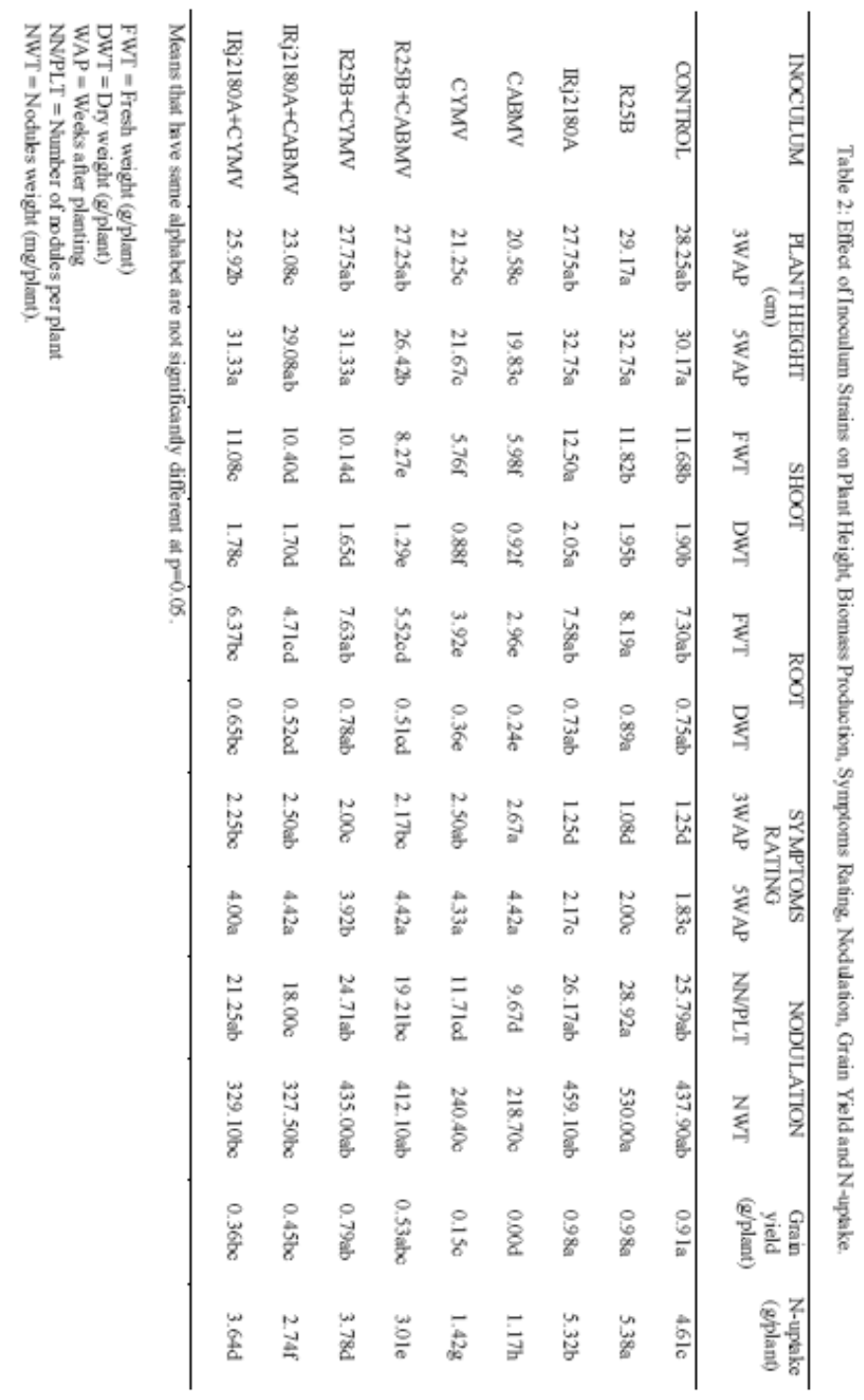

Table 3: Efleot of Time of Inoculation on Phant Height, Biomass Production, Sympioms Rating, Nodulation, Grain Yield and N-uptake

\begin{tabular}{|c|c|c|c|c|c|c|c|c|c|}
\hline \multirow{2}{*}{$\begin{array}{l}\text { TIME } \\
\text { OF } \\
\text { INOC. }\end{array}$} & \multicolumn{2}{|c|}{$\begin{array}{l}\text { PLANT HEIGHT } \\
\text { (cmi) }\end{array}$} & \multicolumn{2}{|c|}{$\begin{array}{l}\text { SYMPTOMS } \\
\text { RATING }\end{array}$} & \multicolumn{2}{|c|}{ NODULATION } & \multirow[t]{2}{*}{$\begin{array}{l}\text { SDW } \\
\text { (g) }\end{array}$} & \multirow{2}{*}{$\begin{array}{l}\text { Grain } \\
\text { yield } \\
\text { (gplt) }\end{array}$} & \multirow{2}{*}{$\begin{array}{c}\mathrm{N}- \\
\text { uptake } \\
\text { (g/ple }\end{array}$} \\
\hline & 3WAP & 5WAP & 3WAP & 5WAP & $\begin{array}{l}\text { Number of } \\
\text { Nodules/plt }\end{array}$ & $\begin{array}{l}\text { NWT } \\
\text { (mg'plt) }\end{array}$ & & & \\
\hline EARLY & $23.72 b$ & $26.48 b$ & $2.67 a$ & $3.85 a$ & $18.54 b$ & $436.95 a$ & $2.68 b$ & $0.59 a$ & $20.32 \mathrm{~b}$ \\
\hline LATE & $27.61 \mathrm{a}$ & $30.26 a$ & $1.26 \mathrm{~b}$ & $3.15 b$ & $22.67 \mathrm{a}$ & $326.95 b$ & $3.60 \mathrm{a}$ & $0.56 a$ & $21.64 a$ \\
\hline
\end{tabular}




\section{Conclusion}

Viruses can and do interfere with rhizobium-cowpea symbiotic relationship. The results obtained established that viruses have a depressive effect on cowpea nodulation process; however, how this is achieved still remains unknown. It was also established that $\mathrm{R} 25 \mathrm{~B}$, a promiscuous isolate of rhizobium possesses a higher resistance than IRj2180A, an isolate of Bradyrhizobium japonicum in resisting viral infections, though, despite its resistance, viruses still manage to interfere with its relationship with cowpea cultivars used. It was further established that CABMV wrecked a greater havoc on rhizobium-cowpea symbiosis than CYMV did. Hence, CABMV was seen as a more pathogenic/devastating virus than CYMV. It was further established that cultivar IT90K-277-2 is a superior genotype to Ife brown and Owode cultivars in terms of growth, resistance to viral infection, biomass production, grain yield and plant tissue $\mathrm{N}$-accumulation.

Based on the foregoing premises, it could be concluded that viruses have negative influences on cowpea growth, nodulation, biomass production, grain yields and even plant $\mathrm{N}$-accumulation. This however is dependent on many factors such as: time of infection, virus and rhizobium strains involved as well as the genetic make-up of the cultivar.

\section{Acknowledgements}

The authors wish to acknowledge the support of soil microbiology unit of the International Institute for Tropical Agriculture (IITA) under the headship of Dr. Sanginga, who provided the facilities and rhizobial materials used for this study. We are also grateful to the virology unit for providing the viral materials used.

\section{References}

[1]. Agrios, G.N., Walker, M.E. and Ferro, D.N. 1985. The effect of cucumber mosaic virus inoculation at successive weekly intervals on growth and yield of pepper (Capsicum annum) plants. Plant Disease, 69: 52-59.

[2]. Allen, D.J. and Lenne, J.M. 1998. The pathology of food and pasture legumes. CAB International, Wallingford, UK. 404pp.

[3]. Bremmer, J.M. and Mulvaney, C.S. 1982. Nitrogen - Total. In: Methods of soil analysis Part 2. Chemical and Microbiological Properties, ASA, Madison, U.S.A. pp 595-624.

[4]. Chant, S.R. 1960. The effect of infection with tobacco mosaic and cowpea yellow mosaic viruses on the growth rate and yield of cowpea in Nigeria. Empire Journal of Experimental Agriculture, 28: 114-120.

[5]. Cooper, J.I. and MacCallum, F.O. 1984. Virus and the Environment. Chapman and Hall, New York. 182pp.

[6]. IITA. 1989. Cowpea Research at IITA. GLIP Research Monograph 1: 1-2

[7]. Kareem, K.T. and Taiwo, M.A. 2007.Interaction of viruses in cowpea: effects on growth and yield parameters. Virology Journal, 4: 15-22.

[8]. Lewin, R.A. 1982. Symbiosis and parasitism - definitions and evaluations. Bioscience, 32(4): 254-259

[9]. Lugtenberg, B.J.J. 1992. Regulation of Nodulation in Rhizobium Leguminosarum. World Journal of Microbiology and Biotechnology, 8(1): 120-123.

[10]. Marconi, E., Lombardi-Boccia, G., Carnivale, E. and Ng, N.Q. 1990. Nutritional evaluation of wild and cultivated species of cowpea. In: N.Q. Ng and L. Monti (eds.) Cowpea Genetic Resources. Pp 101-110.

[11]. Ng, N.Q. and Monti, L.M. 1990. Cowpea Genetic Resources. International Institute for Tropical Agriculture, Ibadan, Nigeria. 200pp.

[12]. Nutman, P.S. 1958. The physiology of nodule formation. In: Nutrition of the legume. Butterworths science publication, London. Pp87-107

[13]. O'Hair, S.K. and Miller, J.C. 1982. Effects of virus infection on N-fixation in cowpea (Vigna unguiculata (L.) Walp.). J. Amer. Soc. Hort. Sci. 107:516-519.

[14]. Panopoulos, N.J., Faccioli, G. and Gold, A.H. 1972. Effects of curly top disease on uptake, transport and compartmentation of calcium. Phytopathology, 62 43-49.

[15]. Sanginga, N., Thottappilly, G. and Dashiell, K. 2000. Effectiveness of rhizobia nodulating recent promiscuous soybean selecti ons in the moist savanna of Nigeria. Soil Biol. Biochem., 32:127-133.

[16]. Shoyinka, S.A. 1974. Status of virus diseases of cowpea in Nigeria. In: Proceeding of the first IITA Grain Legume Improvement Workshop. IITA, Ibadan, Nigeria. Pp $270-273$.

[17]. Shoyinka, S.A., Thottappilly, G., Adebayo, G.G. and Anno-Nyako, F.O. 1997. Survey on cowpea virus incidence and distribution in Nigeria. International Journal of Pest Management, 43(2): 127-132.

[18]. Singh, S.R. and Rachie, K.O. (eds.) 1985. Cowpea Research, Production and Utilisation. John Wiley and Sons, New York. 460pp.

[19]. Stacey, G., Burris, R.H. and Evans, H.J. 1992. Biological Nitrogen Fixation. New York: Chapman and Hall. 943pp.

[20]. Tu, J.C. and Ford, R.E. 1984. Plant-Virus Interaction in Nitrogen-fixing Nodules. Ibid. 91: 200-212.

[21]. Vincent, J.M. 1970. A manual for practical study of root nodule bacteria. Blackwell scientific publication handbook 15 . Oxford, UK. 164 pp.

[22]. Wijesundara, I.I.L., Holm, L.H.J., Kulasooriya, S.A. and Van Holm, L.H.J. 2000. Rhizobiology and nitrogen fixation of some tree legumes native ti Sri Lanka. Biology and Fertility of Soil 30 (5\&6): 535-543. 